Журнал«Герспективитаінноваціїнаукиљ

(Серія «Гедагогіка», Серія «Гиихологія», Серія «Медицин»»

№2(7) 2022

УДК 355.1:159.923

https://doi.org/10.52058/2786-4952-2022-2(7)-892-899

Кротюк Катерина Андріївна аспірант кафедри соціальної та практичної психології, Житомирський державний університет імені Івана Франка, вул. Велика Бердичівська, 40, м. Житомир, 10008, тел..: (063)211-28-11, https://orcid.org/0000-0003-3237-6494

\title{
РІВЕНЬ ПСИХОЛОГІЧНОЇ ТРИВОЖНОСТІ У ВІЙСЬКОВОСЛУЖБОВЦІВ, ЯКІ ПЕРЕБУВАЮТЬ В ЗОНІ ООС
}

Анотація. У статті обгрунтовується актуальність та доцільність дослідження впливу участі бойових дій на рівень тривожності військовослужбовців. Аналіз теоретичних напрацювань дослідників вказує на те, що стан тривожності є невід'ємною складовою існування людини, але в той же час ㄲï надмірні прояви призводять до особистісних дисгармоній, супроводжуються емоційним дискомфортом та мають деструктивний характер.

Специфіка професійної діяльності військовослужбовців пов'язана 3 підвищеною небезпекою, фізичними та психологічними перевантаженнями, 3 високою напруженістю та інтенсивністю. Тривалий вплив такого характеру може зумовити підвищення рівня тривожності, що негативно впливає на характер діяльності військовослужбовця, на здійснення ним професійного обов'язку. Висока тривожність здійснює негативний вплив на мотивацію, активність, бажання розвитку професійних навичок, психічний та фізіологічний стани військовослужбовця.

Емпіричне дослідження особистісної та ситуативної тривожності військовослужбовців-учасників бойових дій ООС показало переважно середній рівень їх вираження. Такі результати військовослужбовців-учасників бойових дій ООС вказують на впевненість в собі та оточенні, відсутність страху та боязкості виконувати складні, психологічно важкі та швидко поставлені завдання. В той же час, не виявлено кардинальних відмінностей у диференціації розподілу рівнів особистісної та ситуативної тривожності. Статистичне встановлення взаємозв'язку результатів дослідження особистісної та ситуативної тривожності військовослужбовців-учасників бойових дій ООС з їх хронологічним віком та досвідом участі в таких умовах не показало значимих кореляційних зв'язків між даними показниками.

Ключові слова: військовослужбовець-учасник бойових дій, військова діяльність, ООС (Операція Об’єднаних сил), особистісна і ситуативна тривожність.

Krotiuk Kateryna Andriivna Postgraduate student of the Department of social and practical psychology, Zhytomyr Ivan Franko State University, Velyka Berdychivska St., 40, Zhytomyr, 10008, tel.: (063) 211-28-11, https://orcid.org/0000-0003-3237-6494 


\section{LEVEL OF PSYCHOLOGICAL ANXIETY OF SERVICEMAN WHO ARE IN ZONE OF JOINT FORCES OPERATION}

Abstract. The article substantiates the relevance and expediency of the study of the impact of hostilities on the level of anxiety of servicemen. An analysis of the theoretical work of researchers indicates that anxiety is an integral part of human existence, but at the same time its excessive manifestations lead to personal disharmony, accompanied by emotional discomfort and destructive.

The specifics of the professional activities of servicemen are associated with increased danger, physical and psychological overload, high intensity and intensity. Prolonged exposure to this nature can lead to increased levels of anxiety, which negatively affects the nature of the activities of the serviceman, the performance of his professional duties. High anxiety has a negative impact on motivation, activity, desire to develop professional skills, mental and physiological condition of the serviceman.

An empirical study of personal and situational anxiety of servicemen participating in combat operations of the Joint Forces Operation showed mainly the average level of their expression. Such results of servicemen participating in the fighting of the Joint Forces Operation indicate self-confidence and environment, lack of fear and apprehension to perform complex, psychologically difficult and quickly set tasks. At the same time, no fundamental differences were found in the differentiation of the distribution of levels of personal and situational anxiety. Statistical establishment of the relationship between the results of the study of personal and situational anxiety of servicemen participating in hostilities with their chronological age and experience of participation in such conditions did not show significant correlations between these indicators.

Keywords: serviceman-a participant in combat actions, military action, Joint Forces Operation, special and situational anxiety.

Постановка проблеми. На теперішній час проблема дослідження психоемоційного стану військовослужбовців-учасників бойових дій стає все більш значимою. Командування військових частин, підрозділів зацікавлені у високій ефективності діяльності підлеглих, їх правильно відпрацьованої тактики ведення бою та готовності в будь-який момент боронити територіальну цілісність України. Звичайно, напружений характер військової служби, чіткі високі вимоги, що постають перед військовослужбовцем, так чи інакше можуть спричинити психологічні порушення та, відповідно, зміни у структурних компонентах військової діяльності. Одним із важливих факторів такого впливу на морально-психологічний стан та бойову ефективність $є$ тривожність.

Аналіз останніх досліджень i публікацій. Одним із грунтовних досліджень, присвячене вивченню тривоги, як стану, і тривожності, як стійкого функціонального утворення, на різних етапах онтогенезу людини $є$ роботи А. Прихожан [4]. Згідно точки зору дослідниці, певний рівень тривожності в нормі властивий всім людям і є необхідним для оптимального пристосування 
людини до дійсності. Наявність тривожності як стійкого утворення свідчить про порушення особистісного розвитку, що перешкоджає ефективній діяльності та комунікації з оточуючими.

В свою чергу, М. Левітов визначає тривожність як психічний стан, що появляється боязкістю і порушенням внутрішнього спокою через вплив зовнішніх загроз [1].

Згідно з науковою позицією С. Соловйової, легка тривожність пояснюється як відчуття небезпеки, що попереджає про можливу загрозливу ситуацію та стимулює організм для іiі подолання [6]. Тривожність пов'язана 3 прогностичними функціями психіки та виконує роль адаптації до будь-яких ситуацій. На думку дослідниці, інтенсивна тривожність (жах, страх) вносить дезорганізуючий вплив на психіку людини, блокує ефективне функціонування психічних функцій. За такого негативного впливу, людина втрачає здатність адекватно оцінювати ситуацію, аналізувати отриману інформацію, створювати гармонійну модель навколишнього середовища та приймати правильні рішення.

Досліджуючи тривожність як якість особистості, Ч. Спілбергер виділив два види тривожності: особистісну та ситуативну (реактивну) [7]. Під особистісною тривожністю розуміється стійка індивідуальна характеристика, яка виявляється у схильності суб'єкта до тривоги і означає наявність в нього тенденції сприймати досить широкий спектр ситуацій як загрозливі. На кожну 3 них людина відповідає відповідною реакцією. Ситуативна (реактивна) тривожність характеризується суб'єктивно переживаючими емоціями, напругою, хвилюванням, нервовістю. Цей стан виникає як емоційна реакція на стресову ситуацію, яка може бути різною за інтенсивністю та динамічністю в часі.

Важливим у вивченні тривожності особистості $є$ визначення чинників іiі формування та розвитку. На думку О. Сумаріна, основними з них $є$ генетична схильність, фізичне та психологічне здоров'я, негативний досвід схожої ситуації та навколишнє середовище [8].

Тривожність у військовослужбовців має свою специфіку. Вона пов'язана 3 підвищеною небезпекою, фізичними та психологічними перевантаженнями, 3 конкретними фруструючими факторами, високою напруженістю та інтенсивністю, необхідністю оволодіння бойовою технікою і зброєю, підготовкою до діяльності, що несе в собі реальну загрозу для життя. Висока тривожність негативно впливає на мотиви і цілі діяльності військовослужбовця, на здійснення ним необхідних дій.

Підтвердженням цього є дослідження Н. Пасинкової про кореляцію рівня тривожності та ефективності військової діяльності [3]. Тривожність підміняє мотив діяльності за рахунок власної спонукальної сили, знижує мотивацію на успіх, сприяє втраті вихідної мети, обумовлює нераціональний вибір вектору діяльності, уповільнює розумові дії, сприяє втраті контролю за складними довільними рухами і порушує координацію мимовільних дій.

Згідно 3 дослідженнями Я. Омельченко та 3. Кісарчук, стан тривожності у військовослужбовців може супроводжуватись як на психологічному 
(напруження, стурбованість, нервозність, почуття невизначеності, безсилля, незахищеності, самотності, неможливості прийняти рішення тощо), так i фізіологічному (посилення серцебиття, зростання частоти дихання та загальної збудливості, підвищенні артеріального тиску, зниження порогів чутливості) рівнях [2].

У власних працях О. Сабадаш описує динаміку тривожності військовослужбовців [5]. Дослідник стверджує, що перед бойовими стрільбами рівень тривожності значно підвищується, під час їх проведення - знижується, а після завершення виконання стрільби - знову підвищується. Причиною цього $\epsilon$ значно вищий вплив очікуваної небезпеки перед реальною загрозою.

Говорячи про причини виникнення стану тривожності у військовослужбовців, які часто перебувають в стресових або екстремальних умовах, варто зазначити, що цей стан $\epsilon$ мінливим i найчастіше сприяє усвідомленню особистістю власного становища в навколишньому світі. Але водночас тривожність може трактуватися як стабільна риса особистості, яка проявляється в регулярній схильності до переживань тривоги в різних життєвих обставинах. Вона визначається станом неусвідомленого відчуття загрози, готовністю сприйняти будь-яку подію як несприятливу або небезпечну. Особистість, яка перебуває в такому стані постійно знаходиться в настороженому та пригніченому настрої, у неї 3'являється страх контакту 3 навколишнім світом.

Умовами, що викликають неспокій та тривогу є: несподівані зміни обстановки, невдачі та помилки під час виконання завдань, можливість виникнення проблем, пов'язаних із специфікою діяльності тощо. Менш впливові форми тривожності $є$ сигналами для усунення недоліків, виховання рішучості, сміливості, впевненості у власних силах. Якщо тривожність виникає 3 невагомих на те причин, є неадекватною до ситуації, що виникла, то такий стан негативно впливає на успішність військової діяльності.

Незважаючи на велику кількість психологічних досліджень, однозначного визначення поняття тривожності немає. Але більшість авторів одностайно стверджують про дезорганізуючий вплив тривожності на діяльність особистості.

Мета статті. Проаналізувавши наукові праці, підходи до визначення поняття та причин тривожності військовослужбовців-учасників бойових дій, ми ставимо за мету дослідження в емпіричному вивченні впливу участі в бойових діях військовослужбовців на їх рівень тривожності.

Гіпотезою дослідження $є$ припущення про деструктивний вплив досвіду участі в бойових діях на рівень тривожності військовослужбовців.

Завданнями дослідження є:

1. Дослідження впливу участі в бойових діях на рівень особистісної та ситуативної (реактивної) тривожності військовослужбовців.

2. Вивчення впливу факторів віку та досвіду участі в бойових діях на рівень особистісної та ситуативної (реактивної) тривожності військовослужбовців. 
Журнал«Герспективитаінновації наукиљ

(Серія «Гедагогіка», Серія «ГТихологія», Серія «Медицин»

№2(7) 2022

3 метою досягнення поставлених завдань дослідження були застосовані психодіагностичні (Шкала оцінки рівня реактивної (ситуативної) та особистісної тривожності Ч.Д. Спілбергера - Ю.Л. Ханіна) та статистичні (Коефіцієнт кореляції Пірсона) методи.

Дослідження проводилось в одній 3 військових підрозділів ЗСУ, що перебувають в ротації Луганської області (зона Операції Об'єднаних сил). Загальна вибірка складає 40 військовослужбовців чоловічої статі дорослого віку, які є учасниками бойових дій ООС різного досвіду служби.

Емпіричне дослідження включає себе:

1. діагностичний та порівняльний аналізи результатів дослідження військовослужбовців-учасників бойових дій;

2. статистичне встановлення взаємозв'язку результатів дослідження особистісної та ситуативної тривожності військовослужбовців-учасників бойових дій з їх хронологічним віком та досвідом участі в таких умовах.

Виклад основного матеріалу. Ситуативна (реактивна) тривожність є станом людини, який характеризує ступінь його побоювання, емоційної напруги щодо ситуації, яка виникає («тут і зараз»).

Особистісна тривожність є якістю особистості, яка визначає ступінь іiі занепокоєння, емоційної напруги внаслідок дії стресових факторів.

Обрахувавши отримані результати дослідження військовослужбовцівучасників бойових дій, ми проілюструємо їх індивідуальні показники на діаграмі (рис. 1).

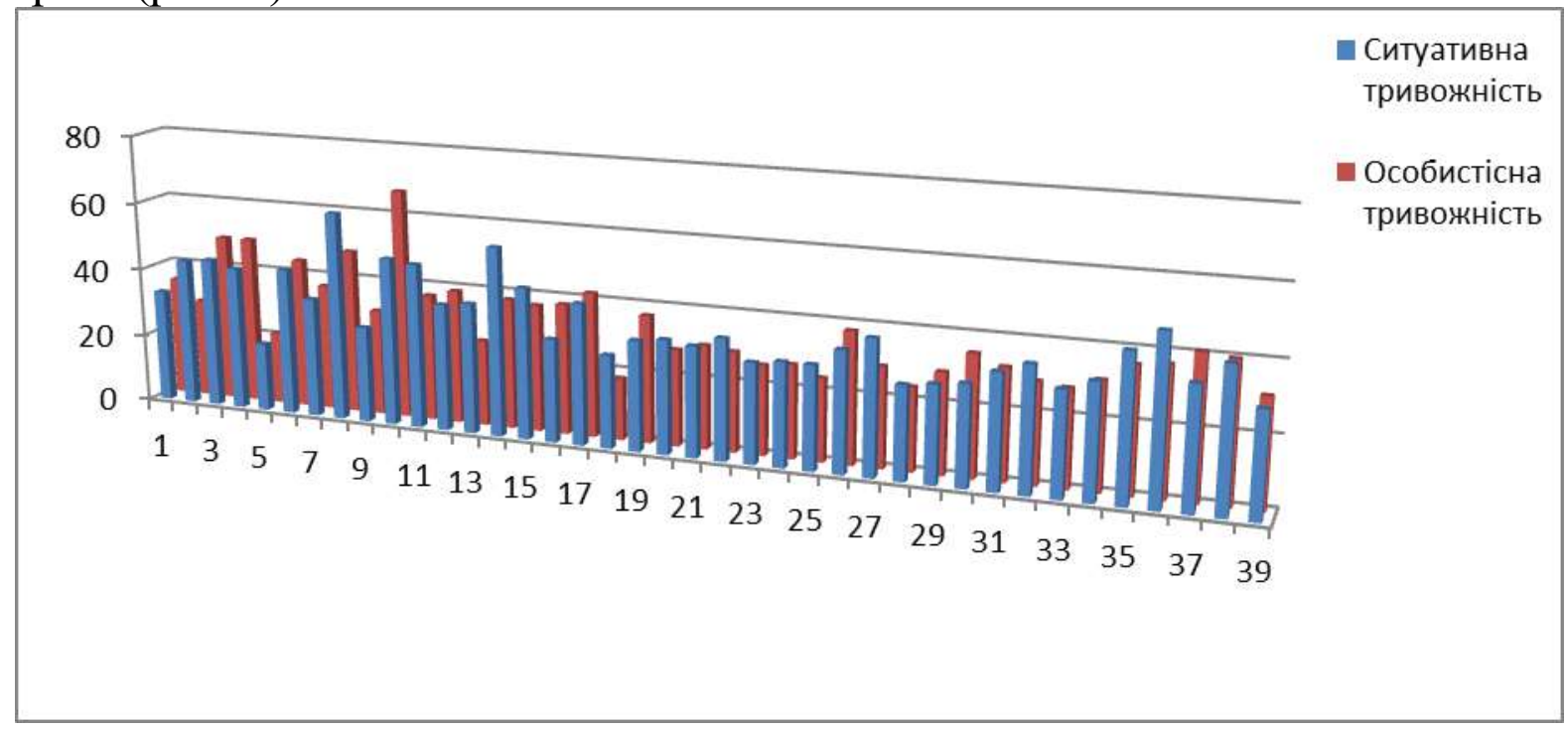

Рис. 1. Індивідуальні показники тривожності військовослужбовцівучасників бойових дій

Для більш змістовного аналізу рівнів тривожності військовослужбовцівучасників бойових дій, ми здійснили їх відсоткову диференціацію. Зведені бали таким методом дають нам змогу побачити тенденцію розподілу досліджуваних за ступенем вираження тривожності в цілому (табл. 1). 
Таблиия 1 Узагальнені результати дослідження рівнів тривожності
військовослужбовців-учасників бойових дій (\%)

\begin{tabular}{|c|c|c|c|c|}
\hline \multirow{2}{*}{$\begin{array}{c}\text { Рівні } \\
\text { тривожності }\end{array}$} & \multicolumn{2}{c|}{$\begin{array}{c}\text { Ситуативна (реактивна) } \\
\text { тривожність }\end{array}$} & \multicolumn{2}{|c|}{$\begin{array}{c}\text { Особистісна (загальна) } \\
\text { тривожність }\end{array}$} \\
\cline { 2 - 5 } & $\begin{array}{c}\text { Кількість } \\
\text { осіб }\end{array}$ & $\begin{array}{c}\text { \% } \\
\text { співвідношення }\end{array}$ & $\begin{array}{c}\text { Кількість } \\
\text { осіб }\end{array}$ & $\begin{array}{c}\text { \% } \\
\text { співвідношення }\end{array}$ \\
\hline Низький рівень & 14 & $35 \%$ & 17 & $42,5 \%$ \\
\hline Середній рівень & 21 & $52,5 \%$ & 19 & $47,5 \%$ \\
\hline Високий рівень & 5 & $12,5 \%$ & 4 & $10 \%$ \\
\hline
\end{tabular}

Показники ситуативної (реактивної) тривожності вказують на те, що у військовослужбовців домінує середній рівень - 52,5\% (21 особа). У 35\% респондентів - був діагностований низький рівень за показниками ситуативної тривожності. Такі отримані результати свідчать про те, що загалом досліджувані не бояться виконувати складні, емоційно насичені, швидко поставлені завдання. Високий рівень виявлено у 12,5\% військовослужбовців. Військовослужбовці, у яких переважає ситуативна тривожність, мають сильну інтенсивність переживань по відношенню до стресових подій, що виникають. Залежно від особистісних властивостей, вона може виражатися, або ж зовсім не мати зовнішнього характеру.

За показниками особистісної тривожності ми бачимо майже рівномірний розподіл результатів за середнім та низькими рівнями особистісної тривожності військовослужбовців (47,5\% та 42,5\% відповідно). Це означає, що респонденти впевнені в собі та мало схильні до занепокоєння. Лише вибіркові загрозливі ситуації можуть вивести їх з емоційної рівноваги. Високий рівень особистісної тривожності у військовослужбовців виявлений лише в $10 \%$ респондентів. Психологічний стан військовослужбовців характеризується постійним хвилюванням за виконання професійної діяльності та 3 приводу широкого кола думок. Тривога може проявлятися в будь-якій ситуації, навіть якщо небезпеки як такої не існує. В такому випадку, досліджувані емоційно виражають власні почуття, нервують. При виконанні професійних завдань, високий рівень тривоги негативно впливає на діяльність, оскільки військовослужбовці не концентруються на ньому та можуть допустити чимало помилок.

Таким чином, аналіз результатів дослідження особистісної та ситуативної тривожності військовослужбовців-учасників бойових дій вказують на відсутність кардинальної відмінності та їх специфіки розподілу.

Застосувавши методи статистичної обробки даних ми не виявили значимих кореляційних зв'язків між показниками тривожності та особистіснопрофесійними характеристиками військовослужбовців-учасників бойових дій. Наприклад, рівень особистісної тривожності військовослужбовців-учасників бойових дій має слабку обернену кореляцію із віком та досвідом служби 
( $r=-0,10$ ma $r=-0,05$ відповідно). Тобто вік та досвід служби не мають значимого впливу на рівень особистісної тривожності військовослужбовцівучасників бойових дій. Кореляційні зв'язки між ситуативною тривожністю та віком й досвідом служби також мають досить слабкий зв'язок $(r=-0,02 \mathrm{ma} r$ =0,19 відповідно). Причиною такого слабкого зв'язку хронологічного віку та досвіду служби із особистісною та ситуативною тривожністю може бути вплив інших факторів, які не враховувались нами під час дослідження.

Отже, в результаті емпіричного дослідження та виконання поставлених завдань, ми визначили загальний розподіл та диференціацію рівнів особистісної та ситуативної тривожності військовослужбовців-учасників бойових дій ООС, виявили специфічні особливості їх зв'язку з особистісно-професійними характеристиками.

\section{Висновки}

1. Аналіз теоретичних підходів та концепцій дослідників вказує, що стан тривожності є невід'ємною складовою існування людини, але в той же час іiї надмірні прояви призводять до особистісних дисгармоній, супроводжуються емоційним дискомфортом, передчуттям небезпеки. Одним із таких чинників стійких тривожних станів $є$ специфіка військової діяльності, яка пов'язана 3 підвищеною небезпекою, загрозою життю і здоров'ю, фізичними та психологічними перевантаженнями.

2. Емпіричне дослідження особистісної та ситуативної тривожності військовослужбовців-учасників бойових дій ООС показало переважно середній рівень їх вираження. В той же час, не виявлено кардинальних відмінностей у диференціації розподілу рівнів тривожності.

3. Статистичний аналіз вихідних даних особистісної та ситуативної тривожності між хронологічним віком та досвідом служби військовослужбовців-учасників бойових дій ООС, не показав значимих кореляційних зв'язків між ними.

Гіпотезу дослідження частково доведено. Перспективи подальшого дослідження полягають у більш детальному визначенні чинників впливу на тривожність, ії динаміки у військовослужбовців-учасників бойових дій ООС.

\section{Лimepamypa:}

1. Левитов Н.Д. О психических состояниях человека. М.: Просвещение, 1964. 343 с.

2. Омельченко Я. Психологічна допомога дітям з тривожними станами. К.: Шкільний світ, 2008. $112 \mathrm{c}$.

3. Пасынкова Н.Б. Связь уровня тревожности подростков с продуктивностью их интеллектуальной деятельности. Психологический журнал. 2006. № 1, С.67-76.

4. Прихожан А. М. Причини, профілактика і подолання тривожності. Психологічна наука і освіта. 1998. № 2, С.11-17.

5. Сабадаш А.Г. Влияние тревожности на обучение военнослужащих. Наука $u$ образование: проблемы и перспективы. Бийск: НИЦ БиГПИ, 2000. С.14-15.

6. Соловьева С.Л. Тревога и тревожность: теория и практика. Медищинская психология 8 России. 2012. № 6 (17). Режим доступа: http://medpsy.ru.

7. Спилбергер Ч.Д. Концептуальные и методологические проблемы исследования тревоги. Стресс и тревога в спорте. М., 1983. 220 с. 
8. Сумарина О.Ю. Тревожность: причины, виды, симптомы. Медицинская психология. 2014. Режим доступа: http://psyera.ru/2696/trevozhnost

\section{References:}

1. Levytov, N. D. (1964). O psykhycheskykh sostoianyiakh cheloveka [About the mental states of a person]. Moscow: Prosveshchenye [in Russian].

2. Omelchenko, Ya. (2008). Psykholohichna dopomoha ditiam z tryvozhnymy stanamy [Psychological help for children with anxiety]. Kyiv: Shkilnyi svit [in Ukrainian].

3. Pasynkova, N. B. (2006). Sviaz urovnia trevozhnosty podrostkov s produktyvnostiu ykh intellektualnoi deiatelnosty [Relationship between the level of anxiety in adolescents and the productivity of their intellectual activity]. Psykholohycheskyi zhurnal - Psychological journal, 1, 67-76 [in Russian].

4. Prykhozhan, A. M. (1998). Prychyny, profilaktyka i podolannia tryvozhnosti [Causes, prevention and overcoming of anxeity]. Psykholohichna nauka i osvita-Psychological science and education, 2, 11-17 [in Ukrainian].

5. Sabadash, A. H. (2000). Vlyianye trevozhnosty na obuchenye voennosluzhashchykh [The effect of anxiety on military`s education]. Nauka y obrazovanye: problemy i perspektyvy - Science and education: problems and prospects, 14-15 [in Russian].

6. Soloveva, S. L (2012). Trevoha y trevozhnost: teoryia i praktyka [Alert and anxiety: theory and practice]. Medytsynskaia psykholohyia v Rossyy - Medical psychology in Russia, 6 (17). Retrieved from http://medpsy.ru [in Russian].

7. Spylberher, Ch. D. (1983). Kontseptualnye y metodolohycheskye problemy yssledovanyia trevohy [Conceptual and methodological problems in the study of anxiety]. Moscow: Stress y trevoha v sporte [in Russian].

8. Sumaryna, O.Iu. (2014) Trevozhnost: prychyny, vydy, symptom [Anxiety: causes, types, symptoms]. Medytsynskaia psykholohyia. Retrieved from http://psyera.ru/2696/trevozhnost [in Russian]. 